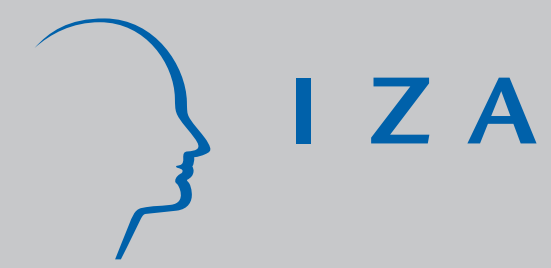

IZA DP No. 8441

Examining the Relationship between Employee Resistance to Changes in Job Conditions and Wider Organisational Change: Evidence from Ireland

Hugh Cronin

Seamus McGuinness

August 2014 


\title{
Examining the Relationship between Employee Resistance to Changes in Job Conditions and Wider Organisational Change: Evidence from Ireland
}

\author{
Hugh Cronin \\ Economic \& Social Research Institute Dublin (Research Intern 2013) \\ Seamus McGuinness \\ Economic \& Social Research Institute Dublin, \\ Trinity College Dublin, NILS, Flinders University and IZA
}

Discussion Paper No. 8441

August 2014

IZA

P.O. Box 7240

53072 Bonn

Germany

Phone: +49-228-3894-0

Fax: $+49-228-3894-180$

E-mail: iza@iza.org

Any opinions expressed here are those of the author(s) and not those of IZA. Research published in this series may include views on policy, but the institute itself takes no institutional policy positions. The IZA research network is committed to the IZA Guiding Principles of Research Integrity.

The Institute for the Study of Labor (IZA) in Bonn is a local and virtual international research center and a place of communication between science, politics and business. IZA is an independent nonprofit organization supported by Deutsche Post Foundation. The center is associated with the University of Bonn and offers a stimulating research environment through its international network, workshops and conferences, data service, project support, research visits and doctoral program. IZA engages in (i) original and internationally competitive research in all fields of labor economics, (ii) development of policy concepts, and (iii) dissemination of research results and concepts to the interested public.

IZA Discussion Papers often represent preliminary work and are circulated to encourage discussion. Citation of such a paper should account for its provisional character. A revised version may be available directly from the author. 


\section{ABSTRACT}

\section{Examining the Relationship between Employee Resistance to Changes in Job Conditions and Wider Organisational Change: Evidence from Ireland}

This paper uses a linked employer-employee dataset, the National Employment Survey, to examine the determinants of organisational change and employee resistance to change and, specifically, to examine the influence of employee inflexibility on the implementation of firmlevel policies aimed at increasing competitiveness and workforce flexibility. Key finding arising from the research is that while workforce resistance to job-related change often forces firms to seek alternative means of achieving labour flexibility, there appears little that firms can do to prevent such resistance occurring. The presence of HRM staff, consultation procedures, wage bargaining mechanisms, bullying and equality polices etc were found to have little impact on the incidence of workforce resistance to changes in job conditions.

JEL Classification: J31, J51, J53

Keywords: workforce resistance, organisational change, linked employer-employee data

Corresponding author:

Seamus McGuinness

Economic and Social Research Institute

Whitaker Square

Sir John Rogerson's Quay

Dublin 2

Ireland

E-mail: Seamus.McGuinness@esri.ie 


\section{Background and Introduction}

Ireland's economic difficulties have been well documented. The international financial collapse had a severe effect on Ireland, the combination of a banking crises and the bursting of a property bubble led to a dramatic fall in economic output and a rapid rise in unemployment. The crises began to be felt by firms towards the latter part of 2008, the data point relevant to this study, with GDP falling by $2 \%$ in that year.

Within a deteriorating economic environment, firms - both domestic and foreign-owned struggle to maintain competitiveness, particularly given that wages remain downwardly rigid even in times of recession (Babecky et al., 2009, 2010; 2012; Bertola et al., 2010; Christopoulou et al., 2010; Autor and Katz, 1999; Fuss, 2008). The majority of the research has found that wage levels generally exhibit downward rigidity, with the probability of wage cuts being lower the more skilled the worker. In terms of theoretical frameworks, downward wage rigidity is consistent with a number of theoretical labour market models such as the efficiency wage theory (Shapiro and Stiglitz, 1984), adverse selection theory (Weiss, 1980) and insider-outsider theory (Lindbeck and Snower, 1988). Consistent with the international evidence, a recent study confirmed that both real average wages and average labour costs increased in Ireland during the course of the recession (Bergin et al, 2012). Given the inflexibility of earnings, it stands to reason that firms tend to seek to improve competitiveness during a recession primarily through other forms of organisational change. In addition, Pfeffer (1994) notes that, with a decreasing competitive advantage provided by traditional sources of success such as product and process technology, how the workforce is managed is comparatively more important. The ability of firms to implement organisational change will undoubtedly be impacted by the extent of co-operation of the workforce which, itself, may be a function of many factors such as the nature and scale of HRM practices, bargaining 
arrangements and industrial sector etc. Nevertheless, the link between workforce resistance and organisational change is under-researched perhaps due to a lack of available data that allows for a linking of employee sentiment to firm-level management strategies. This paper utilises data from a matched employer-employee survey captured at the beginning of the Irish downturn in October 2008. The study captures activity at the very beginning of the economic crises, when the decline in output was still relatively modest and the scale of the recession to come remained largely unforeseen. The research provides a unique assessment of the determinants of firm-level organisational change over a range of dimensions related to employee performance and, more importantly, measures the extent to which such change was impeded or stimulated as a consequence of levels of workforce resistance.

There is a relatively limited literature relating workforce resistance to organisational change. Dow and Perotti (2008) develop a theoretical construct of resistance to change by attempting to explain why established firms fail to adjust to take advantage of opportunities when new firms typically succeed. Dow and Perotti (2008) argues that radical adjustment of assets within the firm can create winners and losers and, consequently, employees whose skills are less valued as a result of proposed changes will tend to resist. The paper predicts modest shifts in the role of different skills can be implemented by consensus but that the likelihood of success diminishes as the desired shift gets larger. Choi (2011) reviews the literature on attitude and organisational change using the keywords 'readiness for change', 'commitment to change', 'openness to change' and 'cynicism about organisational change'. The review highlights research that demonstrates that change-specific commitments, such as commitment to change and cynicism about organisational change, are better predictors of either support for change or resistance to it than general attitudes, such as organisational commitment and organisational cynicism. Choi (2011) concludes that, given their propensity to evolve 
according to the situation, attitudes to change are better conceptualised as states rather than personality traits.

A number of studies have sought to indentify the determinants of resistance to change, some of which have linked workforce resistance with employee level performance. Iverson (1996), tests a causal model predicting employees' acceptance of organisational change in a public hospital in Australia. Using multiple regression, he finds that the most important determinant of acceptance to organisational change is union membership, with members less accepting than non-members. Oreg (2003) developed a measurement scale relating individual worker characteristics to resistance to change across and identifies four reliable factors: routine seeking, emotional reaction to imposed change, cognitive rigidity and short-term focus. Kunze et al (2013) interrogate the assumption of a correlation between age and resistance to change using the scale developed by Oreg (2003). The findings of Kunze et al (2013) contradict the common stereotype of older employees being more resistant to change and the authors suggest this may be due to older employees being more stable and better able to cope with negative emotional reactions to change. The study also finds tenure and occupational status have positive coefficients for resistance to change, while the examination of how resistance to change interacts with individual performance finds individual resistance to change has negative consequences, such as lower efficiency, higher absenteeism due to health problems and the emergence of fewer new ideas. Wanberg and Banas (2000) find that while the characteristic of resilience is not predictive of a more positive view of a given change, it is related to higher levels of change acceptance.

Finally, a number of papers examine the impact of organisational change on workers, thus providing some further understanding of the motivation for resistance. Black et al (2004) find that firms that implement high-performance practices compensate at least some of their workers for such work practices but that there is a significant association between such 
practices and increased wage inequality. Secondly, they find that some forms of organisational change, such as self-managed teams and job rotation, tend to reduce employment levels within the firm. Bryson et al (2013) use a linked employee-employer dataset to study the effects of organisational change on employee well-being in the private sector. The paper finds that change can be introduced without adversely affecting the employee's job-related anxiety by engaging with employees when implementing change but only where one or more unions operate in the workplace. Otherwise, organisational change always increases job-related anxiety.

\section{Data and Methods}

The objectives of this paper are two-fold: firstly, we model the determinants of workforce resistance to job-related change and, secondly, we assess the impacts of such resistance on the probability that firms will implement various wider forms of organisational change. The data is taken from the October 2008 National Employment Survey (NES) and captures the very beginning of the Irish economic recession, when the need for organisational restructuring was likely to be relatively high. The NES is a linked employee-employer survey that is nationally representative of the distribution of employers in Ireland. The employer sample is drawn from the CSO's Central Business Register. Selected firms are asked to extract a systematic sample of employees from payrolls. The dataset covers 10,000 employers and 100,000 employees and the sample generated is representative of the proportion of companies in each economic sector and size class. The employer questionnaire requested information on employee earnings, hours worked and occupation. Information was also obtained on firm size, sector, the use of pay agreements, HRM procedures etc. Employees were issued with a separate questionnaire within which they provided information on age, gender, educational attainment, employment status (part-time or full-time), length of 
time in paid employment, length of service with current employer and also other job-related characteristics (for example, trade union membership, shift-work etc).

The October 2008 survey includes modules on employee resistance and organisational change, with separate employer and employee questions. Employers were asked "Has your business experienced any of the following forms of change in 2008?” with the respondent then providing dichotomous response to nine suggestions: (1) a greater reliance on temporary workers, (2) a greater reliance on part-time workers, (3) an increase in overtime hours, (4) a reduction in the number of management levels, (5) a greater reliance on job-rotation and multi-tasking, (6) a greater reliance on external suppliers of products/services (outsourcing), (7) a downsizing the operation, (8) an increases in the level of staff absenteeism, and (9) increases in the level of involuntary staff turnover ${ }^{1}$. With respect to employee resistance to job-related change, employees were asked "If the following changes were implemented in your workplace over the next two years, how acceptable would you find: (1) an increase in your level of responsibility for your workload, (2) an increase in the level of technology involved in your work, (3) an increase in the level of supervision of your work, (4) an increase in the level of skills necessary to carry out your job, (5) having to work more unsociable hours, (7) an increase in your authority to make decisions, (8) changes to terms and conditions of your employment. In response, employees had the options of 'acceptable', ‘not acceptable’ and no response.

Given that our objective is to identify the factors that influence workforce resistance and the subsequent impact of such resistance on various forms of organisational change, we reduce

\footnotetext{
${ }^{1}$ As changes in the levels of absenteeism and staff turnover are not determined by management, these are not subsequently included as measures of organisational change. Similarly, down-sizing is not considered as this may also be an exogenous influence largely outside of management control.
} 
our linked employer-employee data to the level of the firm by retaining one observation per organisation. In doing so, our employee resistance terms now relate to the average level of resistance within the employing organisation. We retain information from the employer survey and derive a range of organisational average variables based on the employee responses within each organisation. We apply establishment-level weights to our firm-level observations to ensure that our data is representative of the population of firms in Ireland during 2008. Our sample is restricted to private sector organisations only on the grounds that public sector organisations are more insulated from market forces and thus both employees and managers are likely to behave differently both in terms of resistance to change and the need for organisational reform. After exclusions for missing data etc, we retain an effective sample of 4,035 firms.

Moving onto the econometric analysis, our specifications are based around the assumption that our key outcome variables (workforce resistance and organisational change) at the level of the firm will be driven by a combination of the human capital characteristics of the workforce and a range of organisational attributes. Given this, we begin by estimating equation 1 where the dependant variable is binary in nature and indicates that the firm has a incidence of workforce resistance to change in specific areas of job performance that places it in the top quartile of resistant firms. The choice of the cut-off point is somewhat arbitrary -nevertheless, it is fair to conclude that firms selected in this manner can be classified as having the most resistant workforces. Equation 1 is estimated for each of the 7 job-related areas of potential reform. Resistance is modelled as a function of the firm-level characteristics, measured either in terms of variables derived from average employee responses $(\mathrm{H})$, which typically reflect the firm's human capital such as average levels of education and experience, or single response measures (F) taken from the employer survey 
which capture firm-level characteristics such as firm size, sector, HRM practices etc. Subsequent to identifying the drivers of employee level resistance, we then estimate equation 2, which models the determinants of firm-level organisational change as a function of firmlevel characteristics ( $\mathrm{H}$ and $\mathrm{F}$ ) and the binary measures of employee resistance to change (Res). On the grounds that organisational change may be non-random with respect to employee resistance i.e. firms may select into various modes of organisational change based on their observable characteristics which may also be related to levels of employee resistance, a Heckman selection adjustment is added to the models. The selection terms are derived by extracting inverse Mills ratios from equation 1. In order to ensure that the models are properly identified, equation 1 includes a number of additional controls that are omitted from equation $2^{2}$ (see Puhani, 2000).

$$
\begin{gathered}
\overline{\operatorname{Re} s}=\alpha+\beta_{1} \bar{H}+\beta_{2} F+\varepsilon \\
\text { Orgch }=\alpha+\beta_{1} \bar{H}+\beta_{2} F+\beta_{3} \operatorname{Re} s+\lambda \operatorname{Re} s+\varepsilon
\end{gathered}
$$

\section{Results}

Table 1 reports the average proportions of employees stating that a specific change in employment conditions is unacceptable by industrial sector. There was a relatively low level of variation in the level of workforce resistance to change on the various dimensions of employment conditions, with between 20 and 25 per cent of workers indicating that they would resist any attempt to alter aspects of their employment (Table 1). At 20 per cent,

\footnotetext{
${ }^{2}$ The exclusions instruments should ideally have a theoretical basis. In our models we adopt management and individual development programmes and employee incentive schemes such as profit sharing, share incentive, group incentives (productivity incentives based in group performance) and individual incentives (bonuses etc) on the grounds that while such measures may impact employee resistance they will be relatively unimportant in a firms decision to implement change.
} 
workforce resistance was lowest with respect to proposed increases in the number of unsociable hours worked. At 26 percent, workforce resistance was most pronounced with respect to any increase in the skill content of jobs.

There was some substantial variation in the extent of workforce resistance to altered employment conditions across sectors. Subjective resistance was somewhat higher than average in the Financial and Insurance industry, particularly with respect to potential changes to terms and conditions and increases in unsociable hours. Conversely, workforce resistance to many dimensions of job-related change was lower than average within the Construction sector, perhaps reflecting a higher tolerance for harsher working conditions among construction workers. With respect to specific dimensions of workforce resistance across sectors, the potential introduction of new technologies was associated with low levels of resistance in the Real Estate, Professional and Construction industries. Employees in the Health and Social Care sector appeared relatively hostile to the introduction of additional technologies or increased job autonomy.

Table 2 cross-tabulates workforce resistance to changing job conditions by organisational size and demonstrates, very clearly, that workforce resistance across all dimensions of change is strongly and positively correlated with organisational size.

$<$ Insert Table 1 around here $>$

\section{<Insert Table 2 around here $>$}

Table 3 presents the result from equation 1, which models the determinants of employee resistance at the level of the firm across a range of areas related to job performance. The 
dependant variable takes the value 1 if the proportion of employees indicating that they would find change in a particular area unacceptable lies above the $75^{\text {th }}$ percentile, and zero otherwise $^{3}$. As such, the models identify the characteristics of highly resistant firms. We estimate the model using a binary variable, as opposed to the continuous alternative, in order to facilitate the Heckman adjustment in equation 2; nevertheless, the results from a model estimated using a continuous dependant variable are comparable to those presented in Table $3^{4}$. The explanatory variables in our model capture the education and experience composition of the firm, existing work practices, management/HRM structures and employee incentive schemes.

A number of variables are significant with respect to all or most dimensions of workforce resistance, specifically, resistant firms tended to employ lower shares of educated workers. Similarly, a relatively high level of workforce resistance to change in various dimensions of employment conditions was consistently more common in larger firms. Pay levels were largely unimportant; however, workforce resistance to the introduction of new technologies was lower in higher paying firms. Firms employing higher shares of more experience -typically older -- workers were more likely to experience workforce resistance to any increases in workloads or changes to terms and conditions.

Interestingly, both trade union density and the presence of collective bargaining arrangements were not consistently related to workforce resistance; nevertheless, some

\footnotetext{
${ }^{3}$ The exception relates to the variable capturing resistance to an increase in skill requirements. The distribution of this measure was highly skewed to the left and, consequently, the cut-off point was raised to above the $90^{\text {th }}$ percentile in this case.

${ }^{4}$ Results available from the authors.
} 
results were detected. In line with prior expectations, workforce resistance to proposed changes in terms and conditions was positively related to trade union density. The presence of collective wage bargaining arrangements was also found to raise workforce resistance to any proposed change involving increases in either the skill requirements of jobs or levels of supervisory responsibility. Employee consultation also had little impact; however, the collection of worker suggestions was related to a 7 per cent reduction in the probability of workforce resistance to any proposed increases in workloads. The share of workers employed in HRM and the existence of management development procedures had minimal or no impact on workforce resistant to potential changes in employment conditions. The presence of equality policies within the organisation tended to lower the probability of workforce resistance to increases in levels of supervisory responsibility; however, no impacts were found with regard to bullying, health or grievance policies. Organisations implementing individual performance management systems were somewhat less likely to have a workforce resistant to the introduction of new technologies into existing jobs.

The presence of certain financial incentive schemes was found to have some impact on the probability of workforce resistance to changes in working conditions -- specifically, the higher the proportion of employees in profit sharing schemes, the lower probability of resistance across most dimensions of change However, individual incentive schemes raised the likelihood of workforce resistance to any proposed changes in levels of supervision, terms and conditions of employment and skill requirements. The presence of group incentive schemes also exerts a positive impact with regard to resistance to any proposed increase in supervisory requirements. Presumably, if efforts are rewarded on a group basis, this reduces the incentive to take on supervisory duties. Finally, with respect to the Industrial sector, in line with the descriptive statistics, the probability of workforce resistance across most dimensions of change was higher within the Information and communication industry. 


\section{<Insert Table 3 around here $>$}

In Table 4, we model the probability that firms implementing a range of strategies related either the increased labour force flexibility or downsizing. The explanatory variables again include a range of firm-level characteristics; however, we now also include measures of workforce resistance to examine the hypothesis that employee-level inflexibility to changes in job conditions can stimulate, or inhibit, some forms of change related to labour flexibility and competitiveness. As the dependant variables are binary in nature, we estimate probit models (equation 2). We augment the model with inverse Mills ratios (taken from equation 1) to control for the possibility that firms that are workforce resistant will possess characteristics that are also correlated with organisational change. Failure to control for these selection effects may result in biased estimates of the impact of workforce resistance on wider organisational change.

The results from the organisational change models are presented in Table 4. Although the models are well specified, there are few consistent impacts with respect to general firm-level characteristics. Nevertheless, some patterns were evident. Larger firms were more likely to have increased their use of temporary and part-time workers, to have increased their reliance on job rotation/multi-tasking and reduced management levels in the preceding period. Firms employing more experienced staff were less likely to have increased their use of part-time workers $^{5}$. Employee relations variables were more significant, with organisations that had a system of staff consultation more likely to have reduced management levels, increased job rotation/multi-tasking or downsized during 2008. Workplaces with an employee suggestions system were more likely to have outsourced products or services in the months previous to the survey. Firms with a higher share of migrant workers were less likely to have increased

\footnotetext{
${ }^{5}$ Organisations employing higher shares of part-time workers were, unsurprisingly, more likely to have increased their reliance of part-time throughout the year. The result is potentially highly endogenous and should be interpreted with caution.
} 
their reliance on part-time workers during the year, providing some evidence that some employers may treat migrants and part-time workers as substitutes.

Economic sector was an important determinant of organisational change across a number of dimensions. In general, there was broad similarity across sectors, with most sectors displaying negative coefficients, relative to the Mining and quarrying reference group. Positive coefficient effects were more common with respect to outsourcing. The negative coefficient for an increased reliance on job-rotation and multi-tasking was largest in the Transport and storage and Administrative sectors. Firms in the Information and communication, Administrative and Education sectors were least likely to have increased the use of part-time workers. Water and waste firms were most likely to have downsized, while firms in the Administrative and Education industries were least likely to take on part-time workers. Finally, a greater reliance on outsourcing was most common in the Accommodation and Information and communication sectors.

With respect to workforce resistance controls, a number of interesting results emerged. On the whole, there was no strong evidence of sample selection; however, some relationships were detected. Firms whose workforces were resistant to increasing skill requirements and unsociable hours had characteristics also associated with organisations that were more likely to implement change in the areas of management reductions and increased outsourcing. Furthermore, organisations with workforces resistant to changes in terms and conditions tended to have characteristics that generated a lower ex ante expectation that they would introduce job rotation/multitasking.

With regard to the impact of the workforce resistance terms on organisational change, the increased reliance of temporary workers was positively associated with workforce resistance 
to increased levels of supervision. The result is potentially consistent with a scenario whereby a lack of supervision results in a less employee flexibility and/or lower productivity, either of which could necessitate the occasional use of peripheral workers. With regard to an increased usage of part-time employees, this appears to be positively correlated with workforce resistance to proposed increases in workload, technology and supervision; conversely, additional part-time workers were less likely to be hired when workforces were resistant to increased levels of job autonomy. Increases in overtime were more likely in organisations with workforces resistant to changes in terms and conditions, suggesting that such workforces may tend to argue that any benefits arising from increases in product demand should benefit existing employees as opposed to new part-time and/or temporary workers. Management levels were more likely to have been reduced in firms where employees expressed resistance to increases in workloads and were less likely in the presence of resistance to increases in skill requirements. An interpretation of the result is that management levels will tend to be reduced in firms where management have been unsuccessful in delivering worker flexibility and also in low skilled firms.

A number of competing effects were detected with respect to the increased use of job rotation/multitasking, with this form of worker flexibility positively influenced by workforce resistance to increased levels of workload, unsociable hours and changes to terms and conditions. Resistance to increases in technology, supervision and skill content tend to reduce the likelihood of multitasking being introduced. The results suggest that attempts to increase the range of tasks adopted by employees are often a reaction to employee resistance to changing core aspects of their working conditions; however, resistance among workers to acquiring new skills and adopting new technologies constitute a key barrier to the introduction of such policies. Finally, a greater reliance on external suppliers was positively related to workforce resistance to technology and negatively correlated with resistance to 
working unsociable hours.

\section{<Insert Table 4 around here $>$}

\section{Summary and conclusions}

Workforce resistance to proposed changes in job conditions was found to be lower in organisations employing higher shares of educated workers and also in smaller firms. HRM and employee relations measures were found to have little impact on worker resistance to changing employment conditions, while trade union density was important with respect to alterations to core terms and conditions. The level of experience among the workforce and rates of pay was also of relatively little importance in explaining resistance to proposed changes in job conditions. Employee share schemes were found to lower workforce resistance across a range of job-related dimensions; however, the marginal impact of such initiatives on the probability of workforce resistance was low.

Overall, we found that high levels of workforce resistance to proposed changes in a range of areas related to existing employment conditions tended to influence firms' decisions to place a heavier reliance on part-time and temporary workers. With respect to the increased use of job rotation/multitasking, the results suggest that such polices tended to be introduced in firms where the workforce was highly resistant to any changes in their core terms and conditions, suggesting that the need for change may be related to existing worker inflexibility. However, resistance among workers to acquiring new skills and adopting new technologies are a key barrier to the introduction of job rotation/multi-tasking policies. A greater reliance on external suppliers was positively related to workforce resistance to 
increased technology and negatively correlated with resistance to working unsociable hours. Finally, workforce resistance to increases in workload and higher levels of acceptance of new skills was found to be related to management down-sizing decisions.

From a policy perspective, the key finding arising from the research is that while workforce resistance to job-related change often forces firms to seek alternative means of achieving labour flexibility, there appears little that firms can do to prevent such resistance occurring. The presence of HRM staff, consultation procedures, wage bargaining mechanisms, bullying and equality polices etc were found to have little impact on the incidence of workforce resistance to changes in job conditions. 


\section{References}

Babecký, J. Du Caju, P. Kosma, T., Lawless, M., Messina, J., Rõõm, T., Downward Nominal and Real Wage Rigidity: Survey Evidence from European Firms, 2009, ECB Working Paper Series no 1105 / November 2009

Bergin, A. Kelly, E and McGuinness, S, Explaining Changes in Earnings and Labour Costs During the Recession, 2012, Renewal Series, Paper 9, April 2012.

Bertola, G., A. Dabusinskas, M. Hoeberichts, M. Izquierdo, C. Kwapil, J. Montornès and D. Radowski.. Price, Wage and Employment Response to Shocks: Evidence from the WDN Survey 2010, European Central Bank, Working Paper No. 1164

Black, SE, Lynch, LM and Krivelyova, A. (2004). "How Workers Fare When Employers Innovate”, Industrial Relations. Vol. 43 Issue 1, p44-66.

Bryson, A, Barth, E and Dale-Olsen, H. (2013). “The effects of organizational change on worker well-being and the moderating role of trade unions”, Industrial \& Labor Relations Review. Vol. 66(4), pp. 989-1011.

Campbell C, Kamlani, K. (1997). “The Reasons for Wage Rigidity: Evidence from a Survey of Firms”, The Quarterly Journal of Economics, Vol. 112(3), pp. 759-789

Choi, M. (2011). "Employee's attitudes towards organizational change: a literature review”, Human Resource Management, Vol. 50(4), p.479-500

Dow, J and Perotti, E. (2010). "Resistance to change”, FEEM Working Paper No. 48.

Dhyne, E. and Druant, M. (2010). “Wages, labor or prices: how do firms react to shocks?”, European Central Bank, Working Paper No. 1224

Heckman, J. (1979). "Sample selection bias as a specification error”, Econometrica, Vol. 47, pp. 153-61

Ichniowski, C, Shaw, K, and Prennushi, G. (1997). "The Effects of Human Resource Management Practices on Productivity: A Study of Steel Finishing Lines”. American Economic Review, Vol. 87 (3), pp 291-313.

Iverson, R. (1996). "Employee acceptance of organizational change”, The International 
Journal of Human Resource Management, Vol. 7(1).

Kunze, F, Boehme, S, and Bruch, H. (2010) Age, Resistance to change, and job performance: Testing for a common stereotype. Academy of Management Annual Meeting Proceedings. 2010, p1-6.

McGuinness, S., Kelly, E., O'Connell, P. (2010) “The Impact of Wage Bargaining Regime on Firm-Level Competitiveness and Wage Inequality: The Case of Ireland”, Industrial Relations, Vol. 49(4), pp. 593-615.

Oreg, S. (2003). "Resistance to Change: Developing an Individual Differences Measure”.=, Journal of Applied Psychology, Vol. 88(4).

Palley, T. (1990), “A Theory of Downward Wage Rigidity: Job Commitment Costs, Replacement Costs, and Tacit Coordination”, Journal of Post Keynesian Economics, Vol. 12(3), pp. 466-486

Paul, C, and Siegel, D. (2001). "The Impacts of Technology, Trade and Outsourcing on Employment and Labor Composition”, The Scandinavian Journal of Economics, Vol. 103(2), pp. 241-264

Piderit, S.K. (2000). "Rethinking resistance and recognizing ambivalence: a multidimensional view of attitudes toward an organizational change”, Academy of Management Review, Vol. 25(4), pp. 783-794.

Puhani (2000). “The Heckman Control for Selection and its critique”, Journal of Economic Surveys, 14(1), pp 43-69.

Van Dam, K, Oreg, S, and Schyns, B. (2008). “ Daily Work Contexts and Resistance to Organisational Change: The Role of Leader-Member Exchange, Development Climate, and Change Process Characteristics” Applied Psychology: An International Review. Vol. 57(2), pp. 313-334.

Wanberg, C.R. \& Banas, J.T. (2000). "Predictors and Outcomes of Changes in a Reorganizing Workplace”, Journal of Applied Psychology, Vol 85(1), pp. 132-142. 
Table 1: Mean resistance scores by sector

Mean resistance to an increase in:

\begin{tabular}{|c|c|c|c|c|c|c|c|}
\hline Sector & Workload & Technology & Supervision & Skills & Unsociable & Authority & Terms \\
\hline \multicolumn{8}{|l|}{ Mining } \\
\hline Manufacturing & 0.29 & 0.31 & 0.30 & 0.28 & 0.15 & 0.38 & 0.33 \\
\hline \multicolumn{8}{|l|}{ Electricity } \\
\hline \multicolumn{8}{|l|}{ Water \& waste } \\
\hline Construction & 0.18 & 0.13 & 0.17 & 0.17 & 0.16 & 0.17 & 0.19 \\
\hline Wholesale / retail & 0.25 & 0.25 & 0.23 & 0.27 & 0.21 & 0.26 & 0.24 \\
\hline Transport and storage & 0.22 & 0.22 & 0.24 & 0.24 & 0.13 & 0.23 & 0.27 \\
\hline Accommodation & 0.23 & 0.19 & 0.16 & 0.26 & 0.12 & 0.21 & 0.18 \\
\hline Information \& comm. & 0.24 & 0.15 & 0.42 & 0.23 & 0.31 & 0.17 & 0.25 \\
\hline Financial \& insurance & 0.20 & 0.24 & 0.29 & 0.32 & 0.40 & 0.25 & 0.42 \\
\hline Real estate & 0.22 & 0.11 & 0.25 & 0.21 & 0.20 & 0.16 & 0.29 \\
\hline Professional, scientific & 0.19 & 0.12 & 0.32 & 0.27 & 0.27 & 0.14 & 0.20 \\
\hline Administrative & 0.23 & 0.28 & 0.27 & 0.26 & 0.15 & 0.28 & 0.22 \\
\hline \multicolumn{8}{|l|}{ Public } \\
\hline Education & 0.25 & 0.34 & 0.32 & 0.42 & 0.37 & 0.24 & 0.20 \\
\hline Health \& social & 0.29 & 0.40 & 0.20 & 0.35 & 0.24 & 0.41 & 0.26 \\
\hline Arts & 0.30 & 0.29 & 0.28 & 0.30 & 0.18 & 0.27 & 0.31 \\
\hline Other & 0.24 & 0.18 & 0.30 & 0.21 & 0.25 & 0.21 & 0.21 \\
\hline Average & 0.24 & 0.23 & 0.25 & 0.26 & 0.20 & 0.25 & 0.25 \\
\hline
\end{tabular}

Table 2: Mean resistance scores firm size

Mean resistance to an increase in:

\begin{tabular}{lccccccc} 
Size & Workload & Technology & Supervision & Skills & Unsociable & Authority & Terms \\
\hline $1-50$ & 0.23 & 0.16 & 0.23 & 0.24 & 0.20 & 0.20 & 0.20 \\
$50-500$ & 0.30 & 0.38 & 0.31 & 0.31 & 0.21 & 0.41 & 0.40 \\
$500+$ & 0.39 & 0.69 & 0.39 & 0.45 & 0.28 & 0.53 & 0.52 \\
& & & & & & & \\
Average & 0.24 & 0.23 & 0.25 & 0.26 & 0.20 & 0.25 & 0.25
\end{tabular}


Table 3: Determinants of organisational resistance 2008

\begin{tabular}{|c|c|c|c|c|c|c|c|}
\hline VARIABLES & work load & technology & Supervise & Skills & Unsocial & Authority & Terms \\
\hline Mean wage & 0.009 & $-0.046^{* *}$ & 0.029 & -0.016 & -0.018 & -0.008 & -0.037 \\
\hline Mean exper & $0.004 * * *$ & $0.002 *$ & 0.002 & 0.001 & -0.000 & 0.000 & $0.003^{* *}$ \\
\hline \% Male & -0.055 & -0.023 & -0.020 & -0.049 & $-0.1^{* * *}$ & -0.022 & 0.004 \\
\hline \% Part-time & 0.001 & 0.010 & -0.015 & -0.033 & $-0.08^{* *}$ & 0.018 & -0.041 \\
\hline \% basic education & $-0.153^{*}$ & $-0.112^{*}$ & 0.090 & -0.144 & 0.069 & -0.061 & 0.010 \\
\hline \% Secondary education & $-0.23 * * *$ & $-0.197 * * *$ & 0.047 & $-0.25 * * *$ & 0.014 & $-0.18 * * *$ & -0.024 \\
\hline \% Post-secondary & $-0.189 * *$ & $-0.154 * *$ & 0.057 & $-0.23 * * *$ & 0.039 & $-0.17 * * *$ & 0.054 \\
\hline \% Sub-degree & $-0.25^{* * *}$ & $-0.182 * * *$ & 0.005 & $-0.25^{* * *}$ & -0.040 & $-0.18^{* * *}$ & 0.017 \\
\hline \% Third-level & $-0.21 * * *$ & $-0.221 * * *$ & 0.041 & $-0.22 * * *$ & 0.066 & $-0.23 * * *$ & -0.064 \\
\hline \% Shift-workers & 0.039 & $0.042 *$ & $0.110^{* * *}$ & 0.051 & -0.060 & $0.078^{* *}$ & 0.010 \\
\hline \% Professional & -0.056 & -0.024 & -0.013 & -0.040 & 0.007 & $-0.070^{*}$ & 0.000 \\
\hline Firm size & $0.070 * * *$ & $0.030 * * *$ & 0.011 & $0.072 * * *$ & $0.016^{*}$ & $0.090 * * *$ & $0.032 * * *$ \\
\hline TU density & -0.000 & 0.000 & 0.001 & 0.000 & 0.001 & 0.000 & $0.001^{* * *}$ \\
\hline Collective bargaining & 0.058 & 0.007 & -0.008 & $0.081^{* *}$ & -0.031 & $0.072 * *$ & 0.051 \\
\hline Consult on change & 0.014 & 0.022 & -0.004 & 0.003 & 0.018 & -0.002 & -0.016 \\
\hline Worker suggestions & $-0.07 * * *$ & -0.022 & -0.008 & -0.022 & 0.034 & 0.008 & -0.010 \\
\hline HRM share & -0.000 & -0.001 & -0.001 & -0.009 & 0.001 & -0.076 & 0.039 \\
\hline Manage develop & -0.019 & -0.025 & 0.006 & -0.001 & $-0.04 * *$ & -0.003 & $0.053^{*}$ \\
\hline Team perform man & 0.018 & 0.010 & -0.005 & -0.016 & -0.011 & 0.008 & -0.039 \\
\hline Indiv develop & 0.001 & $-0.042 * * *$ & 0.030 & $-0.036^{*}$ & -0.008 & -0.023 & 0.025 \\
\hline \% Migrants & -0.028 & -0.006 & -0.018 & -0.061 & -0.030 & -0.040 & -0.056 \\
\hline Grievance policy & -0.020 & 0.002 & 0.015 & -0.004 & 0.036 & 0.001 & -0.013 \\
\hline Health policy & -0.025 & 0.004 & -0.044 & 0.033 & 0.028 & 0.022 & 0.037 \\
\hline Equality policy & -0.008 & -0.023 & $-0.081^{* *}$ & -0.031 & -0.043 & -0.036 & -0.018 \\
\hline Bullying polcy & -0.001 & -0.017 & 0.032 & -0.001 & 0.017 & 0.007 & 0.020 \\
\hline Indiv incent scheme & -0.000 & 0.000 & $0.001^{* *}$ & $0.001^{* *}$ & 0.000 & -0.000 & $0.001^{* * *}$ \\
\hline Group incent schem & 0.001 & -0.000 & $0.001^{* *}$ & -0.000 & 0.000 & $0.001 *$ & 0.001 \\
\hline Employee share schem & $-0.001^{*}$ & 0.000 & -0.001 & -0.000 & 0.000 & $-0.001^{* *}$ & -0.000 \\
\hline Profit sharing & -0.001 & $-0.001 * *$ & $-0.001^{* *}$ & $-0.001 * *$ & 0.000 & $-0.00 * * *$ & -0.000 \\
\hline \multicolumn{8}{|l|}{ Sector $^{6}$} \\
\hline Manufacturing & $0.330 * *$ & $-0.073 * *$ & $0.327^{* *}$ & $-0.17 * * *$ & 0.134 & 0.128 & $-0.16^{* * *}$ \\
\hline Electricity & -0.069 & $-0.076^{* *}$ & $-0.15^{* * *}$ & 0.009 & & 0.189 & -0.106 \\
\hline Water \& waste & 0.233 & $-0.094 * * *$ & 0.159 & $-0.18^{* * *}$ & -0.009 & 0.119 & $-0.17 * * *$ \\
\hline Construction & $0.286^{* *}$ & -0.066 & $0.238^{*}$ & $-0.25 * * *$ & 0.183 & 0.117 & $-0.201 * *$ \\
\hline Wholesale / retail & $0.317 * * *$ & -0.078 & $0.298 * *$ & $-0.21 * * *$ & $0.197 *$ & $0.159 *$ & $-0.187^{* *}$ \\
\hline Transport and storage & 0.190 & $-0.085^{* * *}$ & 0.239 & $-0.19 * * *$ & -0.029 & -0.011 & $-0.18^{* * *}$ \\
\hline Accommodation & $0.257^{* *}$ & $-0.095^{* * *}$ & 0.211 & $-0.20 * * *$ & 0.123 & 0.037 & $-0.18^{* * *}$ \\
\hline Information \& comm & $0.441^{* * *}$ & -0.059 & $0.459 * * *$ & $-0.147 * *$ & $0.354^{* *}$ & 0.154 & $-0.145^{* *}$ \\
\hline Financial \& insur & $0.295^{* *}$ & $-0.085 * * *$ & $0.340^{* *}$ & $-0.15^{* * *}$ & $0.269 *$ & 0.189 & $-0.138 * *$ \\
\hline Real estate & $0.426 * * *$ & $-0.092 * * *$ & $0.337^{* *}$ & $-0.19 * * *$ & $0.270^{*}$ & 0.033 & -0.128 \\
\hline Professional, scient & $0.383^{* * *}$ & $-0.069 *$ & $0.500 * * *$ & $-0.159 * *$ & $0.295^{* *}$ & $0.231^{*}$ & $-0.152 * *$ \\
\hline
\end{tabular}

\footnotetext{
${ }^{6}$ Nace rev. 2. Mining and quarrying represents the base case in all models.
} 


\begin{tabular}{lccccccc} 
Administrative & $0.281^{* *}$ & -0.056 & $0.377^{* *}$ & $-0.17^{* * *}$ & 0.184 & 0.101 & $-0.18^{* * *}$ \\
Education & $0.552^{* * *}$ & 0.025 & $0.498^{* * *}$ & -0.104 & $0.319^{*}$ & 0.059 & $-0.131^{*}$ \\
Health \& social & $0.437^{* * *}$ & -0.039 & $0.364^{* *}$ & $-0.16^{* * *}$ & $0.340^{* *}$ & $0.302^{* *}$ & $-0.130^{*}$ \\
Arts & $0.433^{* * *}$ & -0.058 & $0.432^{* * *}$ & $-0.17^{* * *}$ & 0.218 & 0.080 & -0.112 \\
Other services & $0.242^{*}$ & $-0.093^{* * *}$ & $0.477^{* * *}$ & $-0.19^{* * *}$ & $0.298^{* *}$ & -0.011 & -0.106 \\
& & & & & & & 4,926 \\
Observations & 4,926 & 4,926 & 4,926 & 4,926 & 4,918 & 4,926 \\
\hline
\end{tabular}


Table 4: Determinants of organisational change

\begin{tabular}{|c|c|c|c|c|c|c|}
\hline VARIABLES & Temp workers & PT workers & Over time & Manage & Rotate & Extern \\
\hline Mean wage & -0.021 & -0.017 & 0.000 & 0.020 & $0.071 *$ & 0.010 \\
\hline Mean exper & -0.001 & $-0.003^{* *}$ & -0.001 & -0.001 & -0.003 & -0.001 \\
\hline \% Male & -0.018 & -0.047 & 0.016 & $-0.055 * *$ & -0.024 & -0.043 \\
\hline \% Part-time & 0.032 & $0.111^{* * *}$ & 0.007 & -0.008 & 0.001 & $-0.051 *$ \\
\hline \% basic education & -0.050 & -0.054 & -0.003 & $-0.15 * * *$ & -0.086 & 0.012 \\
\hline \% Secondary educatio & -0.007 & 0.052 & 0.017 & -0.063 & -0.004 & 0.035 \\
\hline \% Post-secondary & -0.023 & -0.071 & -0.001 & $-0.13 * * *$ & -0.054 & 0.021 \\
\hline \% Sub-degree & -0.063 & 0.027 & -0.003 & -0.023 & -0.001 & 0.058 \\
\hline \% Third-level & -0.021 & -0.053 & 0.027 & -0.058 & -0.177 & -0.005 \\
\hline \% Shift-workers & 0.022 & 0.068 & 0.018 & $0.082 * *$ & $0.204 * * *$ & -0.005 \\
\hline \% Professional body & -0.005 & 0.038 & 0.007 & 0.027 & -0.028 & -0.021 \\
\hline Firm size & $0.019 *$ & $0.033^{* *}$ & 0.004 & $0.052 * * *$ & $0.055^{* *}$ & 0.011 \\
\hline TU density & 0.000 & -0.000 & 0.000 & -0.000 & -0.001 & 0.000 \\
\hline Collective bargaining & -0.001 & -0.010 & -0.008 & 0.002 & -0.078 & -0.027 \\
\hline Consult on change & 0.002 & -0.006 & $0.011^{*}$ & $0.027 * *$ & $0.065 * *$ & 0.018 \\
\hline Worker suggestions & 0.024 & 0.039 & 0.009 & $0.035 *$ & 0.057 & $0.045^{* *}$ \\
\hline HRM share & 0.000 & -0.041 & -0.000 & 0.000 & -0.026 & -0.000 \\
\hline \% Migant & $-0.039 *$ & $-0.090 * *$ & 0.010 & -0.025 & 0.088 & -0.028 \\
\hline \multicolumn{7}{|l|}{ Resistance Terms } \\
\hline Resist workload & 0.752 & $0.995^{* * *}$ & -0.061 & $0.998 * * *$ & $0.952^{* * *}$ & $0.903 *$ \\
\hline Resist technology & -0.267 & $0.957 * * *$ & -0.014 & 0.769 & $-0.573 * *$ & $0.988 * * *$ \\
\hline Resist supervision & $0.997 * * *$ & $0.924 * * *$ & -0.058 & 0.717 & $-0.585^{* *}$ & 0.051 \\
\hline Resist skills & 0.211 & $-0.361^{*}$ & 0.540 & $-0.550 * *$ & $-0.535^{* *}$ & 0.158 \\
\hline Resist unsociable & -0.151 & -0.387 & -0.248 & -0.132 & $0.826 * * *$ & $-0.721 * * *$ \\
\hline Resist authority & -0.095 & $-0.343 * *$ & 0.022 & $-0.395^{*}$ & $-0.475 * *$ & $-0.270 *$ \\
\hline Resist terms & -0.159 & -0.061 & $1.000 * * *$ & 0.541 & $0.972 * * *$ & 0.460 \\
\hline$\lambda$ Workload & -0.204 & $-0.955^{*}$ & 0.069 & -0.495 & -1.296 & -0.291 \\
\hline$\lambda$ Technology & $0.556 *$ & -0.645 & 0.006 & -0.196 & 1.107 & -0.640 \\
\hline$\lambda$ Supervision & $-0.441^{*}$ & -0.463 & 0.064 & -0.203 & 0.677 & -0.033 \\
\hline$\lambda$ Skills & -0.082 & 0.495 & -0.094 & $0.604 * * *$ & 0.579 & -0.074 \\
\hline$\lambda$ Unsociable & 0.210 & 0.572 & 0.247 & 0.162 & -0.711 & $0.946^{* * *}$ \\
\hline$\lambda$ Authority & 0.133 & $0.581 *$ & -0.015 & $0.594 * *$ & 0.526 & $0.452^{*}$ \\
\hline$\lambda$ Terms & 0.215 & 0.040 & $-0.270 * *$ & -0.153 & $-1.640 * * *$ & -0.165 \\
\hline \multicolumn{7}{|l|}{ Sector } \\
\hline Manufacturing & 0.057 & -0.051 & $0.540^{*}$ & -0.042 & -0.196 & $0.485 * *$ \\
\hline Water \& waste & 0.093 & -0.086 & 0.296 & -0.037 & $-0.275^{* *}$ & $0.425^{* *}$ \\
\hline Construction & 0.041 & -0.067 & 0.301 & -0.070 & $-0.294 * *$ & $0.366 * *$ \\
\hline Wholesale / retail & 0.095 & -0.096 & 0.306 & -0.029 & $-0.259 * * *$ & 0.339 \\
\hline Transport and storage & 0.081 & -0.056 & 0.298 & $-0.074 * * *$ & $-0.317^{* * *}$ & 0.225 \\
\hline Accommodation & 0.013 & $-0.101^{*}$ & $0.568^{*}$ & $-0.061 * * *$ & $-0.280 * * *$ & $0.755^{* * *}$ \\
\hline Information \& comm & -0.010 & $-0.099 * *$ & $0.539 *$ & $-0.061 * * *$ & $-0.272 * * *$ & $0.548^{* *}$ \\
\hline Financial \& insurance & 0.200 & -0.001 & 0.546 & -0.034 & $-0.213^{*}$ & 0.411 \\
\hline
\end{tabular}




\begin{tabular}{|c|c|c|c|c|c|c|}
\hline Real estate & -0.015 & -0.072 & 0.482 & -0.056 & $-0.276^{* *}$ & $0.510^{*}$ \\
\hline Professional, scientific & 0.137 & -0.057 & 0.467 & -0.047 & -0.170 & $0.409 *$ \\
\hline Administrative & -0.032 & $-0.134 * * *$ & 0.368 & $-0.061 * * *$ & $-0.334 * * *$ & 0.043 \\
\hline Education & 0.014 & $-0.103 * *$ & $0.633^{* *}$ & $-0.061 * * *$ & $-0.301 * * *$ & 0.041 \\
\hline Health \& social & 0.097 & -0.040 & $0.590^{* *}$ & $-0.066 * * *$ & $-0.295 * * *$ & 0.362 \\
\hline Arts & 0.073 & -0.051 & 0.312 & $-0.062 * * *$ & $-0.264^{* * *}$ & 0.362 \\
\hline Other services & 0.076 & -0.008 & 0.425 & $-0.065^{* * *}$ & $-0.264 * * *$ & $0.498 *$ \\
\hline Observations & 4,918 & 4,918 & 4,918 & 4,918 & 4,918 & 4,918 \\
\hline
\end{tabular}




\section{Data Appendix}

\section{Variable name}

Mean wage

Mean exper

\% Male

\% Part-time

$\%$ basic education

\% Secondary education

\% Post-secondary

$\%$ Sub-degree

$\%$ Third-level

\% Shift-workers

\% Professional

Firm size

TU density

Collective bargaining

Consult on change

Worker suggestions

HRM share

Manage develop

Team perform man

Indiv develop

\% Migrants

Grievance policy

Health policy

Equality policy

Bullying polcy

Indiv incent scheme

Group incent scheme

Employee share scheme

Profit sharing

\section{Workforce resistance}

Resist workload

Resist technology

Resist supervision

Resist skills

Resist unsociable

Resist authority

Resist terms

$\lambda$ Workload

$\lambda$ Technology

$\Lambda$ Supervision

$\Lambda$ Skills

\section{Description}

average gross weekly wage paid to employees in firm

average years sppent in employment by employees of firm

$\%$ share of employees in firm who are male

$\%$ share of employees in firm who are part-time

$\%$ share of employees in firm who have a primary level education

$\%$ share of employees in firm who have a secondary level education

$\%$ share of employees in firm who have a post-secondary level education

$\%$ share of employees in firm who have a sub-tertiary level education

$\%$ share of employees in firm who have a third level education

$\%$ share of employees in firm who are shift workers

$\%$ share of employees in firm who belong to professional bodies

number of employees in firm

$\%$ share of employees in firm who belong to a trade-union

Binary variable indicating that firm has a collection agreement with trade-unions

Binary variable indicating that firm has a sytem in place for consulting with employees

Binary variable indicating that firm has a employee suggestion scheme

$\%$ share of employees in firm who work in HR

Binary variable indicating that firm has a system for developing management competency

Binary variable indicating that firm has a system of team-based performance management Binary variable indicating that firm has a system of individual performance management $\%$ share of employees in firm who are immigrants

Binary variable indicating that firm has a clearly specified grievance policy

Binary variable indicating that firm has a clearly specified health policy

Binary variable indicating that firm has a clearly specified equality policy

Binary variable indicating that firm has a clearly specified bullying policy

$\%$ share of employees who participate in individual incentive schemes

$\%$ share of employees who participate in group incentive schemes

$\%$ share of employees who participate in share schemes

$\%$ share of employees who participate in profit sharing schemes

Binary variable: firm is in highest quartile for workforce resistance to increased workload Binary variable: firm is in highest quartile for workforce resistance to increased technology Binary variable: firm is in highest quartile for workforce resistance to increased supervision Binary variable: firm is in highest quartile for workforce resistance to increased skills Binary variable: firm is in highest quartile for workforce resistance to unsociable hours Binary variable: firm is in highest quartile for workforce resistance to increased autonomy Binary variable: that firm is in highest quartile for workforce resistance to changes in terms continuous variable, mills ratio from resistance to increased workload equation continuous variable, mills ratio from resistance to increased technology equation continuous variable, mills ratio from resistance to increased supervision equation continuous variable, mills ratio from resistance to increased skills equation 
$\Lambda$ Unsociable

$\Lambda$ Authority

$\Lambda$ Terms

\section{Organisational change}

Temp workers

PT workers

Over time

Manage

Rotate

Extern continuous variable, mills ratio from resistance to unsociable hours equation continuous variable, mills ratio from resistance to increased autonomy equation continuous variable, mills ratio from resistance to changes in terms and conditions equation

Binary variable indicating that firm increased its reliance on temporary workers

Binary variable indicating that firm increased its reliance on part-time workers

Binary variable indicating that firm increased its reliance on overtime

Binary variable indicating that firm reduced management numbers

Binary variable indicating that firm increased its reliance on job rotation / multitasking

Binary variable indicating that firm increased its reliance on external suppliers 